\title{
EMANSIPASI WANITA DAN PERAN IBU (KAJIAN TEMATIK DAN PSIKOLOGIS PENDIDIKAN ANAK USIA DINI)
}

\author{
Oleh: Ivan Riyadi \\ PPs UIN Sunan Kalijaga, Jl. Marsda Adisucipto Yogyakarta \\ e-mail: ivanriyadi91@yahoo.com
}

\begin{abstract}
Abstrak
Based on the thematic and psychological studies that the role of the mother is very significant for young children, mothers act as educators and models for children. Then this article aims to explore which refers to the books of literature, using the form of theories, concepts, where the presentation is descriptive by using research methods literature. Challenges to be faced by the woman currently in the proemancipation, which must be running multiple roles without having to leave his nature as a woman. On one hand, Women are required to always be "productive " in the career and life of its people. However, on the other hand for a woman who has not had a partner they should serve the elderly. And if it already has a spouse, a woman devoted to her husband prosecuted. As well as being a mother and role model for his children. That is what will be the biggest challenge for the woman
\end{abstract}

Keywords: Emansipasi Wanita, Peran Ibu, Pendidikan Anak Usia Dini

\section{A. Pendahuluan}

Pendidikan anak usia dini merupakan hal yang sangat penting, sebab anak usis dini adalah generasi penerus masa depan, di tangan merekalah ditentukan tegaknya suatu bangsa, eksisnya suatu agama dan kehormatan sebuah keluarga. Dengan demikian pendidikan anak harus dipersiapkan, direncanakan dan diberikan secara baik dan benar serta optimal sesuai dengan 
irama pertumbuhan dan perkembangannya, sehingga akaln lahir generasi yang beriman, bertakwa, cerdas, terampil, berbudi luhur dan berakhlak mulia serta berguna bagi keluarga, bangsa dan negara.

Dalam mendidik anak di usia dini diperlukan peran aktif seorang ibu, pada saat ini terkadang Emansipasi Wanita, atau diterjemahkan secara gamblang. Bahwasanya Wanita itu sama dengan Pria. Tentu saja definisi itu salah besar. Masyarakat juga harus memahami makna kesetaraan gender yang sebenarnya. Karena pada dasarnya Pria dan Wanita memiliki peranan masing-masing dalam kehidupanya. Peran kaum Wanita tidak serta-merta menghilangkan peran kaum Pria. Namun, Wanita juga memiliki hak dan kewajiban dalam mengemban tanggung jawab, baik itu berupa karir ataupun dalam kehidupan keluarga, masyarakat, bangsa dan negara. Tentunya jasa dari Raden Ajeng Kartini sangatlah bermanfaat bagi kehidupan bangsa Indonesia khususnya bagi kaum Wanita. Hal ini dibuktikan dengan adanya Wanita memegang peran penting dalam membangun bangsa.

Demi membangun Indonesia tanpa diskriminasi. Kaum wanita juga tidak boleh melupakan hakikat sebagai seorang wanita. Sudah seharusnya mereka menyadari kodratnya sebagai seorang wanita, yang diharapkan nantinya menjadi pendidik pertama bagi anak-anaknya kelak. Sudah sepantasnya wanita sebagai sosok yang dihormati dan dihargai serta dilindungi dari berbagai kekerasan dan ancaman. Namun, sudah menjadi tugas wanita pula mengingatkan makna kebebasan dan emansipasi yang sebenarnya terhadap generasi muda. Mengingat emansipasi sudah banyak yang disalahartikan. 
Saat ini nama Kartini telah menjadi legenda sekaligus menjadi simbol perjuangan bagi kaum wanita. Tepat tanggal 21 april nanti, bangsa Indonesia khususnya kaum Wanita akan memeperingati hari lahir Raden Ajeng Kartini, yang saat ini kita kenal dengan hari emansipasi wanita. Momentum tersebut haruslah menjadi sarana dalam memaknai hakikat kesetaraan gender yang sesungguhnya. Kehidupan yang serba modern menjadi tantangan tersendiri bagi kaum Wanita dalam mengambil peran dari berbagai bidang kehidupan. RA Kartini merupakan sosok yang fundamental sekaligus fenomenal, beliau patut menjadi panutan bagi kaum Wanita masa kini.

"Bangsa yang besar adalah bangsa yang tidak pernah melupakan sejarah dan jasa-jasa pahlawannya yang berjuang hanya untuk bangsa tercinta ini.

Ir. Soekarno sebagai generasi penerus bangsa, sudah sepantasnya kita dapat memanfaatkan dan menghargai apa yang telah diperjuangkan oleh R.A. Kartini dengan sebaik-baiknya. Salah satunya dengan menjunjung tinggi hak-hak kaum wanita serta menjadikan wanita sebagai subjek dan bukan hanya sebagai objek. Sudah saatnya "kartini masa kini" mencatatkan dirinya sebagai pelaku emansipasi yang mampu mengambil peran demi terciptanya bangsa Indonesia yang lebih baik dan bermartabat. Tanpa harus menghilangkan hakikat dan kodratnya sebagai seorang Wanita. "Habis gelap terbitlah terang" semoga cita-cita dan spirit Kartini selalu terpendam dalam hati seluruh masyarakat Indonesia dan senantiasa menjadi penerang dalam memajukan apa yang telah beliau perjuangkan sebelumnya. 


\section{JURNAL AL-AFKAR}

Vol. III, No. 1, April 2015

Namun dalam era modernisasi ${ }^{1}$ dimana perubahanperubahan sosial terjadi sengat cepat, telah mempengaruhi nilainilai kehidupan, termasuk dengancorak kehidupan keluarga modern. Peran dan fungsi ibu terpengaruh akibat emansipasi wanita, didorong pula oleh kemajuan ilmu pengetahuan dan teknologi membuat inu modern turut bersama bapak memasuki lapangan pekerjaan di luar rumah. Keadaan ini membuat ibu tidak dapa lagi memuasatkan perhatiannya pada pendidikan anak (terutama pendidikan anak usia dini).

Terlepas dari kesibukan orang tua bekerja di luar atau karena kurang begitu memahami peran dan fungsinya yang terpenting sebagai pendidikan utama dan pertama bagi anak, menyebabkan pendidikan anak tidak optimal diberikan oleh orang tua. Sebagaimana dijelaskan oleh Zakiah Darajat bahwa dalam fenomena sehari-hari, pendidikan anak di keluarga terjadi secara alamiah tanpa disadari orang tua, padahal pengaruh dan akibat sangat besar. ${ }^{2}$

Kebebasan wanita dahulu sangat dibatasi. Budaya patriarki sangat didewakan pada masa itu, dudukan dan derajat wanita dianggap lebih rendah daripada pria. Oleh karena itu, mereka tidak memiliki kebebasan sebagaimana yang dimiliki oleh kaum pria. Baik itu kebebasan mengeyam pendidikan, kebebasan

\footnotetext{
1 Kata-kata modern, modernisme, modernisasi, seperti kata lainnya yang berasal dari barat, telah dipakai dalam bahasa Indonesia. Dalam masyarakat barat modernisme berarti pikira, aliran, gerakan dan usaha-usaha untuk mengubah paham-paham, adat-istiadat, institusi-institusi lama dan sebagainya, agar semua itu menjadi sesuai denga pendapat-pendapat dan keadaan-keadaan baru yang ditimbulkan oleh ilmu pengetahuan dan teknologi modern. Lihat, Harun nasution, Islam Rasional: Gagasan dan Pemikiran, (Bandung; Mizan, 1995), cet. Ke-3, hal. 181.

2 Zakiah Darajat, Pendidikan Islam dalam Keluarga dan Sekolah, (Jakarta:Ruhamana, 1995), Cet. Ke-2, hal.74.
} 
bekerja, kebebasan memiliki jabatan bahkan kebebasan atas pendapat. Semua hal tersebut tidak dimilik oleh kaum wanita.

Atas dasar itulah Raden Ajeng Kartini sebagai seorang gadis yang dilahirkan di lingkungan priayi dan dari keluarga yang maju. merasa bahwa dirinya harus membawa kaumnya dari belenggu adat istiadat masyarakat, yang berpendapat bahwa "Derajat Wanita itu lebih rendah daripada kaum Pria". Kartini mengawali perjuangannya dengan mencoba mendirikan sekolah untuk anak-anak gadis di kota kelahirannya Jepara. Ia merasa bahwa ia harus mengangkat derajat dan martabat seorang wanita melalui ilmu pengetahuan. Berbekal tekad dan kemauan keras ia terus berupaya dalam rangka memperbaiki nasib kaum wanita disekitarnya. Atas dasar itulah Kartini terus tergerak hatinya untuk membawa perubahan dan mengupayakan gerakan emansipasi Wanita pada saat itu.

M. Fauzil Adhim (Psikolog yang juga penulis buku-buku keluarga) menerangkan juga bahwa masish banyak kaum perempuan yang menjalani peran keibuannya berdasarkan instink dan pola turun temurun semata bukan sebagai sebuah pilihan sadar yang diiringi dan kemauan untuk meningkatkan terus menerus kualitas peran keibuan. Peran ibu dijadikan sebagai urutan kedua setela berumah tangga, mereka tidak memiliki konsep tentang anak. ${ }^{3}$ Kebanyak ibu-ibu belum mengerti pentingnya pendidikan anak di rumah, mereka beranggapan anak akan pandai jika di sekolahkan. Kesimpulannya sebagai pendidik peranan ibu sangat besar, namun ibu-ibu di kota maupun di desa belum dapat memberikan isi yang kata dalam berinteraksi dengan anak.

3 M. Fauzil Adhim, "Bangsa Menjadi Ibu”, Ummi, Edisi 8/Xii/2001, hal. 8 


\section{JURNAL AL-AFKAR}

Vol. III, No. 1, April 2015

Peran wanita sebagai ibu merupakan naluri kewanitaan akan tetapi pada saat ini di era emansipasi wanita terkadang disalah pahami oleh sebagian wanita. Fakta masih ada anggapan wanita yang tidak ingin mempunyai anak dengan alasan masalah rumah tangga yang merepotkan serta adalah hak dia untuk memilih atau tidak mau berperan sebagai ibu, meskipun seorang wanita mempunyai kodrat mengandung, melahirkan dan menyusui.

Padahal kehadiran orang tua (khususnya ibu) dalam pertumbuhan dan perkembangan anak pada usia dini adalah amat penting. Jika anak kehilangan peran dan fungsi ibunya dalam perhatian, pembinaan, pendidikan, kasih sayang, maka anak tersebut mengalami deprivasi material ${ }^{4}$ dan dapat menyebabkan anak terhambat dalam perkembangan inteligensinya, rapuh pertahanan mentalnya dan lemah fisiknya.

Dadang hawari menjelaskan akibat deprivasi material dan deprivasi paternal bahwa anak tersebut beresiko tinggi menderita ganggyan perkembangan kepribadian, yaitu perkembangan mental-intelektual, perkembangan mental-emosional dan perkembangan psiko-sosial serta perkembangan spritual. Tidak jarang dari mereka bila kelak telah dewasa akan memperlihatkan berbagai perilaku yang menyimpang, anti sosial bahkan sampai kepada tindak kriminal. ${ }^{5}$ Islam memberikan peluang yang besar dan sama bagi kaum wanita untuk berkiprah baik dalam linlgkungan keluarga maupun sosial dalam rangka menjalankan fungsi kekhilafahan manusia di muka bumi oleh karena

\footnotetext{
${ }^{4}$ Kehilangan Sesuatu Dibutuhkan (Peran Ibu) oleh Anak, Bila Peran Ayah Tidak Erfungsi Deprivasi Peternal Dan Jika Peran Kedua Orang Tua Tidak Berfungsi Deprivasi Parental.

5 Dadang Hawari, Al-Qur'an: Ilmu Kedokteran Jiwa dan Kesehatan Jiwa, (Yogyakarta: Dana Bakti Prima Jasa, 1997), Cet. Ke-3 hal. 172
} 
pendidikan anak dalam keluarga adalah tanggung jawab kedua orang tua, baik ayah atau ibu secara bersama-sama. Namun dalam fakta empiris, ibulah yang mengandung, melahirkan dan menyusui anak sehingga psikologis ibu lebih dekat pada anak terutama pada masa awak kehidupanya.

Islam menjelaskan bahwa ibu adalah seorang yang dianugrahi oleh Allah tugas mulia yaitu kemampuan untuk mengandung, melahirkan dan menyusui anak, yang secara implisit menerangkan perangan ibu yang penting yaitu sebagai pendidik dan teladan bagi anak-anaknya teruatama di masa usia dini. Pendidikan ibu terhadap anak dimulai sebelum seorang wanita menikah dengan melakukan persiapan-persiapan untuk menjadi seorang ibu yang baik. Hal inilah yang penting dan menarik bagi penulis untuk diperhatikan oleh ibu dalam mendidikan anak pada usia dini.

\section{B. Pembahasan}

Sebagai seorang wanita dalam kehidupan sehari-hari memainkan peran sebagai anggota keluarga, ibu rumah tangga, istri, pendidik anak. Sebagai peran ibu kaum wanita memiliki peran yang sangat penting bagi anak, sebab secara fakta empiris ibu adalah orang yang paling dekat dengan anak khususnya pada awal pertumbuhan dan perkembangan anak.

Masa awal pertumbuhan dan perkembangan anak adalah sangat penting sebagai dasar kelangsungan kehidupan selanjutnya. ${ }^{6}$ Hurlock berpendapat bahwa masa kanak-kanak

${ }^{6}$ Hurlock menujukkan empat pembuktian yang menjelaskan dasar awal anak sangat penting, pertama hasil belajar dan pengalaman awal memunyai peran dominan dalam perkembangan dan bertambahnya usia anak serta bimbingan awal yang baik akan menjadi fondasi atau rel yang baik bagi anak sehingga kecil kemungkinan kelak anak akan beralih ke rel yang salah, kedua dasar awal dapat 
khususnya lima tahun pertama merupakan masa krisis bagi seorang anak yang akan berpengaruh pada proses perkembangan selanjutnya. ${ }^{?}$

Pada saat usia 5 tahun seorang anak sangat membutuhkan kedekatan sama ibu, akan tetapi pada saat ini banyak ibu yang menjadi tulang punggung keluarga sebagai penopang kebutuhan keluarga. Selain, mengurus dan mengasuh anak-anak mereka. Hal itu menegaskan, kaum ibu tidak hanya berperan mengurus rumah tangga semata. Terkadang, ia juga sebagai penopang keluarga. Para Srikandi itu tak kenal lelah mengasuh, mendidik, dan juga ikut membantu perekonomian keluarga. Tak berlebihan memang, bila hari ibu diadakan, mengingat ketulusan para ibu dalam mengurus keluarga. Kasih sayang ibu menjadikan anak-anak mereka dapat mencapai cita-cita mereka. Peran ibu merupakan salah satu penentu keberhasilan seorang anak dalam kehidupannya.

Menurut kak seto: usia lima tahun pertama seorang anak merupakan masa kritis, karena pada usia inilah terjadi pembentukan struktur dasar kepribadian seorang anak. ${ }^{8}$ Pada lima tahun pertama terjadi perkembangan inteligensi yang cepat. Penelitian bloom secara longditudinal menunjukkan bahwa pada anak usia 4 tahun sudah berkembang $50 \%$ dari variansi inteligensi orang dewasa, yang dianggap mencapai perkembangan

berkembang menjadi kebiasaan, ketiga pola sikap dan perilaku yang dibentuk pada awal kehidupan anak cendrung bertahan, keempat perubahan cepat yang bijaksana oleh orang-orang yang dekat dengan anak akan membuat anak mau bekerja sama dalam mengadakan perubahan. Lihat. Elizabeth B. Hurlock, Child development, (Newyork: McGraw-Hill, Inc, 1978). hal. 27.

7 Ibid, hal. 25

8 Sintong Silaban, Pendidikan Indonesia Dalam Pandangan Lima Belas Tokok Pendidikan Swasta, (Jakarta; Dasamedia, 1993), hal. 224. 
optimal pada usia 17 tahun. ${ }^{9}$ Demikianlah pendapat beberapa ahli psikologi tentang pentingya pendidikan, pembinaan anak sejak usia dini, membekas sangat mendasar dan mendalam. Sedangkan dalam pandangan Islam pendidikan anak dimulai jauh sebelum anak lahir yaitu sejak pemilihan calon suati-istri dengan tuntutan-tuntutan yang telah diajarkan Islam, sebab potensi yang ada pada kedua orang tua akan menurun pada anak yang akan lahir.

Namun pada masa kini, emansipasi wanita biasanya dijadikan alasan untuk seorang ibu meninggalkan peran mengurus rumah tangga. Mereka terlena akan kepuasan yang mereka usung sebagai emansipasi di luar batas. Akibatnya, anak lebih dekat dengan pengasuh yang sehari-hari mengurus mereka, dan ibu pun dianggap orang lain. Itu mungkin elegi saat ini. Karier yang mereka anggap sebagai aktualisasi diri, menjadikan peran seorang ibu harus luput dari anak mereka. Bimbingan serta arahan seorang ibu yang tidak didapat anak, menjadikan anak jauh dari kasih sayang. Sehingga tidak jarang, saat ini, banyak anak mengabaikan perkataan orangtua. Mungkin, salah satu faktornya adalah hilangnya kedekatan orangtua, terutama ibu.

Ibu sebagai pendengar anak-anak dan tempat untuk menceritakan masalah mereka. Perhatian ibu akan menjadikan anak dapat berkembang di dalam kehidupan sosial dengan baik. Peran yang memang sangat vital dimiliki seorang ibu dalam keluarganya. Bagaimana jika peran tersebut hilang? Untuk itu, di samping sebagai wanita karier yang memang menuntutnya bekerja, peraan ibu mengurus anak jangan terabaikan. Sesibuk

9 F.j. Monks, Psikologi Perkembangan Pengantar Dalam Berbadai Bagiannya, (Yogyakarta: Gadjah Mada Universiti Press, 2001), cet. Ke -13, hal. 239. 
apapun orangtua, khususnya ibu, harus dapat membimbing dan mengasuh anak mereka. Sebab, pendidikan dasar bagi anak adalah pendidikan dalam keluarga, yang akan menjadi dasar untuk pendidikan formal selanjutnya. Emansipasi memang suatu hal yang sangat positif jika digunakan dengan baik. Para ibu akan membuahkan karya dengan berbagai kesempatan yang didapat dalam berkarier. Hal itu juga harus diselaraskan dengan perannya untuk keluarga.

\section{Tinjaun Psikologis Peranan Ibu dalam Mendidik Anak Usia Dini}

Allah SWT menciptakan manusia dengan dua jenis, laki-laki dan wanita. Dari segi fisik dan psikis ada perbedaan antara dua jenis tersebut dan telah dibuktikan oleh penelian ilmiah yang dimuat dalam berbagai tulisan atau media. Dalam pandangan Islam, perbedaan ini tidak menunjukkan dan tidak berarti bahwa yang satu lebih tinggi atau lebih mulia dari yang lain. Perbedaan ini dipandang sebagai pembagian peranan manusia dalam proses kehidupan agar tercipta harmonisasi.

Di antara anugerah Tuhan yang hanya diberikan kepada kaum wanita adalah kemampuan untuk mengandung, melahirkan dan menyusui. Oleh karena itu, apakah mungkin jika sala satu jenis manusia mendapat tugas secara biologis kemudian tidak dilengkapi dengan persiapan jiwa ataupun raga yang khusus pula? Jika salah satu jeis manusia mendapatkan kekhususan untuk mengandung, melahirkan dan menyusui mungkinkah hal itu tidak diikuti denan penyiapan jenis diri itu (perempuan), baik dari segi perasaan, emosi dan cara berpikir agar siap untuk menghadapi kejadian khususu itu yang merupakan peristiwa 
besar serta agar dapat memenuhi segala hal yang dapat dihadapi dari peristiwa itu? Tuhan yang maha bijaksana dan maha besar, memberikan kemampuan bagi kaum wanita baik secara fisik maupun psikis agar mereka dapat melaksanakan peran sebagai ibu atau keibuan.

Dalam Kamus Besar Bahasa Indonesia keibuan berarti sifat-sifat ibu (lemah lembut, penuh kasih sayang). ${ }^{10}$ Keibuan berkaitan dengan relasi atau hubungan ibu denga anaknya sebagai kesatuan fisiologis, psikis dan sosial. Relasi tersebut dimulai sejak janin berada dalam kandungan ibunya kemudian berlanjut denga proses-proses fisiologis pada masa hami dan kelahiran, masa menyusui dan memelihara, mengasuh, merawat sera mendidik nak. Semua fungsi fiologis tersebut selalu diiringi dengan komponen-komponen psikologis, yang pada setiap jenis memiliki tipe yang khas dan sama sifatnya. Namun secara individual menunjukkan adanya perbedaan, oleh karena sifatsifat kepribadian setiap individu wanita memang berbeda.

Adapun sifat-sifat keibuan, secara garis besarnya menurut kartini kartono dapat digolongkan dalam dua ide yaitu: ${ }^{11}$ pertama, kualitas tertentu dari karakter dan kepribadia wanita yang bersangkutan. Kedua, gejala emosional pada wanita tersebut, yang bersumber pada ketidak berdayaan bayi atau anak; sebab bayi atau anak selalu bergantung dan membutuhkan pertolongan serta pemeliharaan dari ibunya.

Sifat keibuan di dalamnya terkandung perasaan yang halus (mulia), jiwa pengorbanan yang tinggi, kesabaran terhadap beban

\footnotetext{
${ }^{10}$ Depdikbud, Kamus Besar Bahasa Indonesia, (Jakarta: Balai Pustaka, 1997), hal. 365. ${ }^{11}$ Kartini kartono, Psikologi Wanita: Mengenal Wanita Sebagai Ibu dan Nenek, (Bandung: Mandar Maju, 1992), jilid 2, hal. 30.
} 
yang terus-menerus, ketelitian dan perhatian dalam melaksanakan tugas. Sifat-sifat itu merupakan peritiwa jiwa, emosi dan pola pikir seorang ibu untuk menyeimbangkan persiapan ragawi dalam melaksanakan tugas mengandung, melahirkan dan menyusui. Hubungan segi fisikdan psikis antara satu dengan yang lain saling menunjang, dimana akan terjadi ketimpangan bila salah satu tidak ada atau diabaikan.

Quraish Shihab menegaskan keibuan adalah rasa yang dimiliki oleh setiap wanita yang normal, karenaya wanita selalu mendambakan seorang anak untuk menyalurkan rasa keibuan tersebut. Mengabaikan potensi ini berarti mengabaikan jati diri wanita. ${ }^{12}$ Sebagian besar kompleks kejiwaan yag dialami oleh orang dewasa adalah akibat dampak negatif dari perlakuan yang penanggung jawab utama terhadap perkembangan jiwa dan mental anak, khususnya saat usia dini. Disini agama menoleh kepada ibu, yang memiliki keistimewaan yang tidak dimiliki ayah, bahkan tidak dimili oleh wanita-wanita selain ibu kandung seorang anak. Sifat-sifat keibuan tersebut sangat dibutuhkan oleh anak terlebih di awal pertumbuhan dan perkembangannya.

Menurut Harun Nasution, tugas asli dan utama istri sebenarnya adalah menjadi ibu rumah tangga. Tugas ibu rumah tangga bukan semata-mata memasak dan mengatur rumah, tetapi lebih penting dari itu adalah mendidikan anak-anak baik fisik maupun spirit dan mentalnya. Pendidikan di rumah merupakan dasar dan di atas dasar inilah pendidikan selanjutnya di tegakkan. Kalau pendidikan dasar ini tidak kuat atau tidak benar, maka pendidikan selanjutnya akan mempunyai dasar yang tidak benar dan salah. Dengan demikian akan muncullah

${ }^{12}$ M. Quraish Shihab, Secervah Cahaya Ilahi: Hidup Bersama Al-Qur'an, (Bandung: Mizan, 2000), hal 212-213. 
anggota masyarakat yang pertumbuhan dan pendidikannya tidak tepat. ${ }^{13}$ Jelas kiranya bahwa pendidikan di rumah di bawa asuhan ibu mempunyai hubungan erat dengan masa depan bangsa dan negara.

Saat ini jumlah wanita yang berada dalam angkatan kerja sudah hampir menyamai jumlah pria. Industrialisasi, urbanisasi, kemajuan ilmu pengetahuan dan teknologi telah mendorong terjadinya perubahan peran sosial budaya dari kaum wanita. Bila dulu jenis pekerjaan yang dapat dan boleh dilakukan wanita amat terbatas, sekarang kondisnya sudah jauh berbedaa bahkan seorang wanita dapat menduduki posisi sebagai pimpinan sebuah negara.

Gejala ini di satu pihak amat membesarkan hati karena memang dari dulu sudah timbul aspirasi dari pihak wanita untuk dapat berkembang sampai bawas tertinggi dari kemampuannya. Sudah selayanya kebiasaan dan berbadai norma dalam kebudayaan tidak lagi menghambat kaum wanitas untuk berkembang seirama dengan kaum wanita. Menghadapi kenyataan ini, maka kehadiran orang lain atau suatu lembaga yang dapat membantu ibu dalam mengasuh dan merawat anak selama ia bekerja di luar rumah sangat dierlukan. Keberadaan seorang ibu pengganti (surrogate mother) dan tempat penitipan anak menjadi satu alternatif untuk membantu ibu bekerja agar perkembangan anak baik secara fisik, psikis, dan sosial masih kecil jika dia pergi bekerja.

Anak adalah pewaris masa depan, oleh karena itu perlu dipersiapkan secara matang untuk menghadapi segala macam tantangan kehidupa. Anak yang shaleh yang mendoakan kedua

${ }^{13}$ Harun Nasution, Islam Rasional: Gagasan dan Pemikiran, (Bandung: Mizan, 1995), cet. Ke-3, hal. 43. 
orang tua adalah penyelemat bagi orang tuanya. Agar anak dapat tumbuh dan berkembang dengan optimal, maka kebutuhan dasar yakni nutrsi, kesehatan, emosi kasih sayang, stumulasi, pengasuhan dan pendidikannya harus dipenuhi. Dengan demikian kam ibu harus mempunyai pengetahuan yang cukup dan wawasan yang luas untuk melaksanakan tugasnya.

Mengapa orang tua seolah-olah mampu membuat takdir anak, apakah ia layak ke surga ataukah ke neraka? Semua anak terlahir suci, hingga orang tanya mencoretkan berbagai coretan yang membentuk kepribadian yang menetap dalam dirinya. Selain memberikan kasih sayang yang bisa menjadikan seorang anak berakhlak baik, orang tua juga menentukan masa depan anak selanjutnya. ${ }^{14}$

Pendidikan anak usia dini memberikan pengaruh dan kontribusi yang sangat besar bagi pengembangan diri anak selanjutnya. Sebab pendidikan usia dini merupakan fondasi bagi dasar kepribadian anak. Pendidikan anak usia dini dapat dijadikan cermin untuk melihat bagaimana keberhasilah anak di masa mendatang. Anak yang mendapatkan layanan yang baik semenjak usia 0 tahun hingga usia 8 tahun memiliki harapan lebih besar untuk meraih keberhasilan di masa mendatang.

Anak yang tidak mendapatkan pelayanan yang memadai membutuhkan perhuagan yang cukup berat untuk mengembangakan kehidupan selanjutnya. ${ }^{15}$ Anak yang mendapatkan pembinaan sejak usia dini akan dapat meningkatkan kesehatan dan kesejahteraan fisik dan mental,

\footnotetext{
${ }^{14}$ Nurul Khamaria, Menzalimi Anak Tanpa Sadar 12 Kesalahan Yang Sering Terjadi dalam Mendidikan Anak (Solo: Aqwam, 2010), hal. 96.

${ }^{15}$ Hibana s. Rahman, Konsep Dasar Pendidikan Anak Usia Dini, (Yogyakarta; PGTI Press, 2002) hal. 4-5.
} 
yang itu akan berdampak pada peningkatan prestasi belajar dan etos kerja serta produktif.

Pendidikan anak usia dini adalah suatu proses pembinaan tumbuh kembang anak usia lahir hingga enam tahun secara menyeluruh, yang mencakakup aspek fisik dan non fisik, dengan membeerikan rangkasangan bagi perkembangan jasmani, rohani (moral dan spritual), motorik, akal pikir, emosional dan sosial yang tepat agar anak dapat tumbuh dan kembangka secara optimal. Adapaun upaya yang dilakukan mencakup stumulasi intektual, pemeliharaan kesehatan pemberian nutrisi, dan penyediaan kesempatan yang luas untuk mengeksplorasidan belajar secara aktif. ${ }^{16}$ Dengan demikian PAUD merupakan pemberian upaya untuk menstimulasi, membimbing, mengasuh, dan pemberian kegiatan pembelajaran yang akan menghasilkan kemampuan pada anak.

Memperlihatkan konsep Islam bahwa pendidikan itu dimulai dari buaian dan berakhir hingga ke liang lahat atau long life education, jelas menunjukkan bahwa Islam mengakui adanya pendidikan dalam keluarga yakni terutama disaat anak masih kecil. Bahkan bukan itu saja karena pendidikan anak di lingkungan keluarga adalahyang paling awal, maka ia menempati posisi yang sangat penting dan mendasar atau sebagai penyangga pendidikan anak pada usia dini.

Sepanjang hidup, manusia umumnya pasti melalui proses pengasuhan dari orang tua, paling tidak dalam jangka waktu tertentu, sebab tidak mungkin seorang anak begitu dilahirkan langsung diserahkan kepada orang lain untuk memeliharanya.

${ }^{16}$ Bambang Hartoyo, Konsep Dasar Pendidikan Anak Usia Dini, (Jawa Tengah: 2004), hal. 3 
Anak membawa fitrah dan potensi tetapi sekaligus memiliki kelemahan-kelemahan keluarga harus berusaha mengembangkan fitrah dan potensi di awal pertumbuhannya dan berusaha agar kelemahan yang terbawa sebagai tabiat manusia tidak tumbuh melebihi pertumbuhan fitrah dan potensinya.

Anak harus ditanamkan kalimat tauhid merupakan hal yang pertama yang harus dimasuk atau diperdengarkan dan diajarkan kepada anak sebagai penanaman dasar-dasar keimanan. Itu berarti kalimat tauhid merupakan hal urgen yang harus mendasar rumusan kurikulum yang akan dibentuk.

\section{Penutup}

Berdasarkan dua kajian (tematik dan psikologis) diketahui bahwa keberadaaan ibu sangat berati bagi anak di usia dini, ibu berperan sebagai pendidik dan model bagi anak. Oleh karena itu, pengetahuan ibu tentang hal yang berkaitan dengan anak meliputi gizi, kesehatan, pertumbuhan dan perkembangan anak serta ajaran-ajaran Islam mutlak diperlukan dan dipersiapkan agar ibu dapat memberikan pendidikan yang sesuai dengan perkembangan dan kebutuhan anak secara optimal sesuai dengan ajaran Islam supaya terbentuk pemimpin-pemimpin masa depan yang baik.

Psikologi memandang ibu sebagai seorang yang melahirkan anak dan menjadi pengasuh yang sah bagi anak dimana keberadaan dan kehadiran ibu pada awal pertumbuhan dan perkembangan anak sangat penting, dibuktikan dari hasil penelitian bahwa masa dini anak adalah masa kritis, masa pembentukan fisik, pembentukan inteligensi dan pembentukkan kepribadian yang akan menentukan pertumbuhan dan perkembangan anak. 


\section{DAFTAR PUSTAKA}

Harun nasution, Islam Rasional: Gagasan dan Pemikiran, Bandung; Mizan, 1995

Zakiah Darajat, Pendidikan Islam dalam Keluarga dan Sekolah, Jakarta:Ruhamana, 1995.

M. Fauzil Adhim, “Bangsa Menjadi Ibu”, Ummi, Edisi 8/Xii/2001.

Dadang Hawari, Al-Qur'an: Ilmu Kedokteran Jiwa dan Kesehatan Jiwa, Yogyakarta: Dana Bakti Prima Jasa, 1997.

Elizabeth B. Hurlock, Child development, Newyork: McGraw-Hill, Inc, 1978.

Sintong Silaban, Pendidikan Indonesia Dalam Pandangan Lima Belas Tokok Pendidikan Swasta, Jakarta; Dasamedia, 1993.

F.j. Monks, Psikologi Perkembangan Pengantar Dalam Berbadai Bagiannya, Yogyakarta: Gadjah Mada Universiti Press, 2001.

Depdikbud, Kamus Besar Bahasa Indonesia, Jakarta: Balai Pustaka, 1997.

Kartini kartono, Psikologi Wanita: Mengenal Wanita Sebagai Ibu dan Nenek, Bandung: Mandar Maju, 1992, jilid 2.

M. Quraish Shihab, Secervah Cahaya Ilahi: Hidup Bersama AlQur'an, Bandung: Mizan, 2000.

Harun Nasution, Islam Rasional: Gagasan dan Pemikiran, Bandung: Mizan, 1995, cet. Ke-3.

Nurul Khamaria, Menzalimi Anak Tanpa Sadar 12 Kesalahan Yang Sering Terjadi dalam Mendidikan Anak, Solo: Aqwam, 2010.

Hibana s. Rahman, Konsep Dasar Pendidikan Anak Usia Dini, Yogyakarta; PGTI Press, 2002. 